\title{
Max Meyerhof and his contributions in the history of ophthalmology in the Middle East
}

\section{Max Meyerhof y su quehacer en la historia de la oftalmología del Medio Oriente}

\author{
Rolando Neri-Vela ${ }^{1 *}$, Luis Sánchez-Fernández² and Ericka X. Medina-González ${ }^{1}$ \\ ${ }^{1}$ Naval Medical School, Commission for Historical Studies, Military Medical School, Mexico City, Mexico; ${ }^{2}$ Faculty of Medicine, University of Oviedo, \\ Asturias, Spain
}

\begin{abstract}
One of the best academics in the history of ophthalmology in the Middle East was Max Meyerhof. One of his great contributions was collecting original papers in the bazaars in old Cairo, as well as learning Arabic, surrounding himself of scholars, translating those old manuscripts and introducing them to the West. In this work, we remember his intellectual contributions.

Key words: Max Meyerhof. Ophthalmology. Middle East. Trachoma.

\section{Resumen}

Uno de los más grandes estudiosos de la historia de la oftalmología en el Medio Oriente fue Max Meyerhof, que entre sus grandes trabajos se dedicó a recopilar fuentes originales en los bazares de El Cairo y a aprender el árabe, rodeándose de hombres sabios, traduciendo esos antiguos escritos y dándolos a conocer al mundo occidental. Hacemos en este trabajo un recuento de su quehacer intelectual.
\end{abstract}

Palabras clave: Max Meyerhof. Oftalmología. Medio Oriente. Tracoma.

In the $19^{\text {th }}$ century, the interest in learning about the history of science in the medieval Arab and Islamic world began and, thus, one of the best known historians of Islamic medicine, Claudius F. Mayer, and other nineteenth-century European thinkers, like Sylvestre de Sacy, author of the Anthologie grammaticale arabe, George W. Freytag, who wrote Lexicon Arabo-Latinum (1837), F. Wüstenfeld, author of Geschichte der arabischen Ärzte, Göttingen (1840), were given the task of studying the roots of that history, together with Julius
Theodore Zenker, who compiled a bibliography for Arabists, Gustav Flügel, R. Seligmann, the French Lucian Leclerc, who published his Histoire de la médecine arabe in Paris in 1876, August Müller, editor of the Arabic text of Ibn Asaibi'a' about the biography of the scientists of his time, written in the $13^{\text {th }}$ century and published in Cairo in 1882, Edward W. Lane, recognized for his translation of Arabian Nights and for his Dictionary of the Arabic language, Moritz Steinschneider, the great scholar in Semitic language, whose

Correspondence:

${ }^{*}$ Rolando Neri-Vela

Tuxpan, 16-401

Col. Roma

Date of reception: 12-11-2019

Date of acceptance: 17-05-2020

C.P. 06760, Ciudad de Mexico, Mexico

E-mail: drnerivela@ hotmail.com
Available online: 09-11-2020 Rev Mex Oftalmol (Eng). 2020;94(6):249-252

www.rmo.com.mx (http://creativecommons.org/licenses/by-nc-nd/4.0/). 
publications include Die arabische Literatur der Juden (1902), and Brockelmann, whose basic history of Arabic literature was published at the end of the century (Geschichte der arabischen literatur, 1898-1902).

Since the successful Napoleonic expedition arrived to Egypt in 1788, that part of the planet became an attraction for oculists due to its wide spread of eye diseases. There arrived Tachau, who introduced modern ophthalmology and was called by the Arabs iláh-el'ayin, the god of the eyes, and Robert Koch, in 1883, who had discovered a year earlier the tuberculosis bacillus, and who also found Vibrio cholera and the cause of Egyptian ophthalmia. Morax also came from Paris, as well as Fuchs, Kuhnt and Julius Hirschberg, who was in those lands in 1889'.

Julius Hirschberg, an eminent ophthalmologist and ophthalmology historian, together with two orientalist friends, Lippert and Mitwoch, spent a long time collecting, studying and translating Arabic manuscripts on eye diseases, to publish his work on Arabic ophthalmology in 1905. Hirschberg and his collaborators opened a new area of study in the history of Arab science.

One of the personalities who contributed to this branch of human thought was Max Meyerhof (Fig. 1), born in Hildesheim on March 21, 1874 into a Jewish family in which several scientists and doctors had distinguished themselves. His maternal uncle was Dr. Otto Spiegelberg, a gynecologist in Breslau and Göttingen; two of his cousins became famous for their studies, Dr. Wilhelm Spiegelberg, professor of Egyptology at Strasbourg, and Dr. Otto Meyerhof, chemist and physiologist, who worked on the chemistry of enzymes and was awarded the Nobel Prize in Medicine in 1922.

Max Meyerhof studied in Heidelberg and finished his studies in Strasbourg around 1897. He was then an approbierter Arzt, without being a medical doctor; to obtain his medical degree he would have to write a doctoral dissertation.

At the time, bacteriology was still a novelty, and Meyerhof was strongly drawn to it. He did a one-year stay, in 1897, at the Hygienisch-Bakteriologisches Institut, of the University of Strasbourg, where, under the tutelage of Professors E. Levy and J. Forster, studied the biology of Proteus, its pathogenicity and resistance to heat, and graduated in 1898.

During his postgraduate studies in Ophthalmology he was constantly reminded that Egypt was an important place for the study of eye diseases: at that time, Tourtechot de Granger, who had published his work Relation $d u$ voyage fait en Egypte in Paris in 1745, had already called the country «the land of the blind»?2.

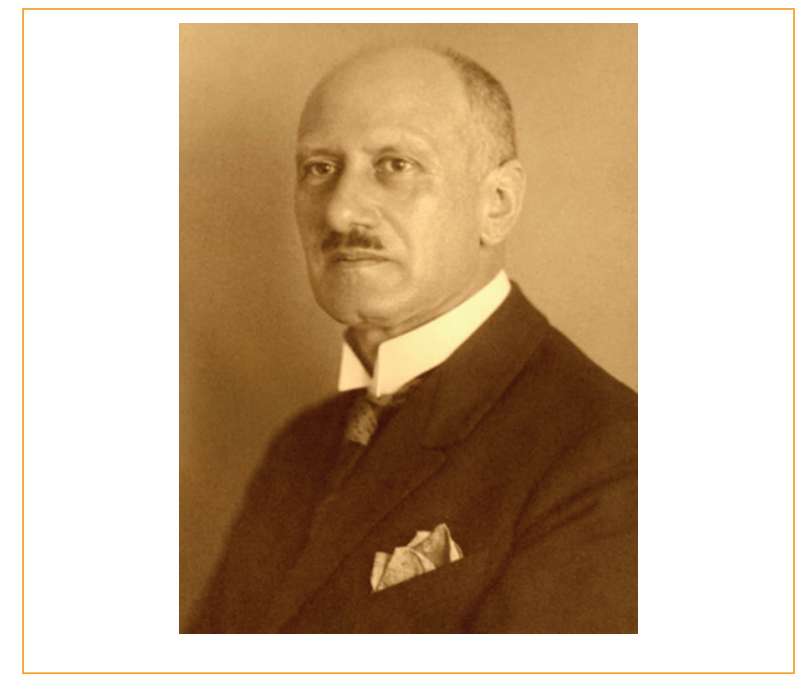

Figure 1. Max Meyerhof.

While Meyerhof was in Bromberg, he was invited by his family to accompany his cousin Otto Meyerhof, whom his doctor had recommended to visit Egypt to fully recover his health, affected by some kidney disease. In December 1900 he arrived to Egypt with great anticipation, as there was much to see and much interest for a budding ophthalmologist. Next to its pyramids, the Sphinx, the museums, the mosques of Cairo and the health facilities of Assuan and Heluan, Meyerhof could not be of medical help at that time, but he was impressed by the large number of people who were blind, one-eyed and with weak vision, that abounded in the streets, in the bazaars and in the schools, throughout the length and breadth of the country.

Meyerhof, eager to visit eye hospitals, investigated their situation, and to his surprise discovered that there were none, that ocular diseases were misdiagnosed, that trachoma was confused with seasonal conjunctivitis and that there was no ophthalmology society.

After his stay in Cairo he returned to Germany, but in October 1903, he returned again to Cairo, taking with him letters of recommendation for the German community and for the German directors of several medical institutions.

While setting up his private practice and gaining experience with Egyptian folklore, Meyerhof was spending most of his time, before World War I, on his ophthalmology research.

Meyerhof was president of the Egyptian Ophthalmological Society in 1908 and $1909^{3}$.

His first relationship with the history of medicine was the search of unpublished Arabic manuscripts in the 


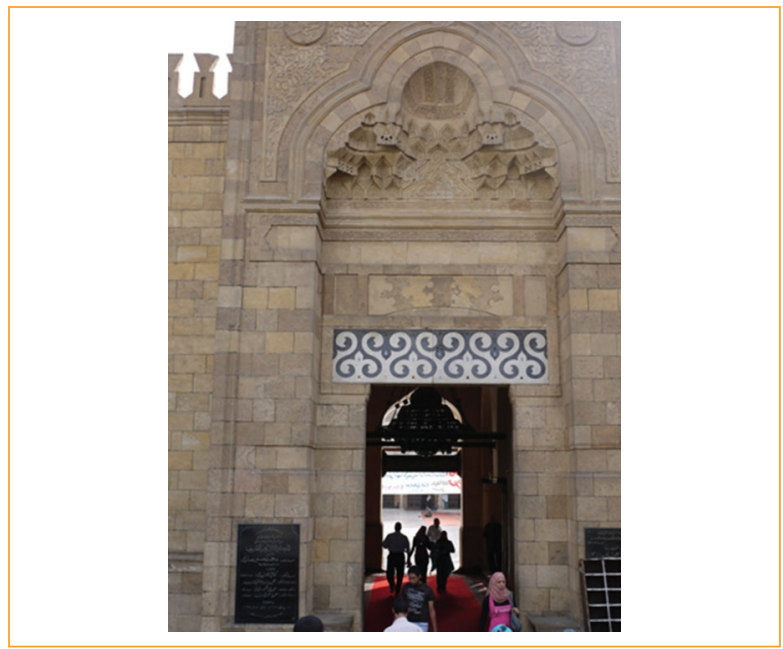

Figure 2. Al-Azhar Mosque, Cairo.

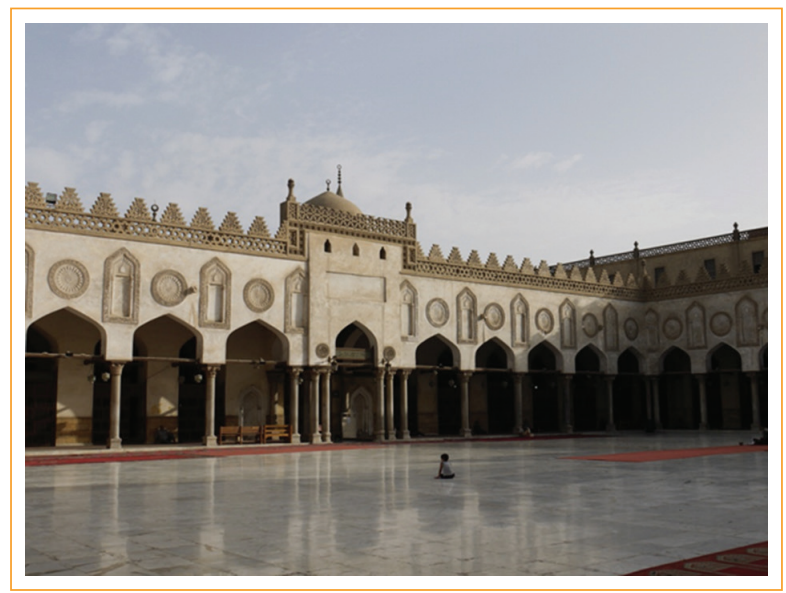

Figure 3. Al-Azhar Mosque, Cairo.

bookstores of the Khedive neighborhood and around the al-Azhar mosque (Figs. 2 and 3), in 1905. Later, his visits to bookstores in Cairo became more frequent. His friendship with the sage Ahmad Taimur Pasha and with the orientalists of various countries, made him an eminent historian of medieval Arab medicine ${ }^{3}$.

The rise of nationalism was beneficial, and even welcome, for Meyerhof's organizing efforts, since, in his 1905 demands, the statements were essentially the same on the medical side as those of the nationalists on the political side, according to Mayer: 1) a campaign against superstition, quackery and indolence of the native Egyptians; 2) education of Egyptians regarding cleanliness and better water supplies; 3) appropriate distribution of expert physicians throughout the country for the control of glaucoma and trachoma, and
4) preparation of many hospital wards for patients with eye disorders ${ }^{3}$.

In 1908, during his presidency of the Egyptian Ophthalmological Society, he was able to witness with joy the birth of a new hospital in Tanta, and that the Egyptian parliament contemplated a budget for the expansion of hospitals.

During the Second World War years, while residing in Germany, Meyerhof had a consulting room in Hannover, but he spent most of his time among orientalist scholars. It was Professor Moritz, director of the library of the Oriental Seminary in Berlin and whom Meyerhof had met in 1905, when Moritz was director of the Khediva Library in Cairo, who encouraged Meyerhof to search Arabic ophthalmology manuscripts. There were many other people who encouraged him in this endeavor, such as Eilhard Wiedemann and Stigler in Erlangen, Ernst Seidel in Meissen, Seligmann in Hamburg, Horovitz in Frankfurt and Mittwoch, Georg Schweinfurth, Schäffer, Frank and Ruska in Berlin ${ }^{3}$.

During Max Meyerhof's second stay in Egypt, from 1923 to 1945 , opportunities for ophthalmology research increased: the Egyptian government decided to use certain funds derived from the war for the construction of an ophthalmology laboratory and, after some formalities, Meyerhof worked there. Thus, during the day his work was spent in ophthalmology and his free hours at night were devoted to the study of Arabic manuscripts about medicine, botany and pharmacology, and, since 1928, about the lives of Jewish doctors who had practiced in the Arab world in the Middle Ages.

The result of his inquiries was an almost uninterrupted series of publications. In 1928, the University of Bonn granted him an honorary doctorate, and in 1931 he became an honorary member of the Royal Society of Medicine ${ }^{3}$.

He was an active writer for about 47 years, from 1898 , when he published his medical dissertation, until his death.

Meyerhof felt that he had met the requirements indicated by Julius Hirschberg for a medical historian. He was an expert in his medical specialty and studied the Arabic language under the guidance of E. Littmann, a wise Arabist, in addition to the help and cooperation of his German friends in Egypt.

Since 1905, when he began his visits to the Khedive Library, today the National Library of Egypt, and after visiting others, such as the one in the old al-Azhar mosque, he hired an Arab copyist to transcribe any Arab ophthalmology material he found ${ }^{3}$. 
On a visit to the druggist 'Abd-al-Magid, in a bazaar full of herbs, seeds, arsenic and eye paints, he found a $15^{\text {th }}$-century manuscript by Dá'úd al-Antáki on Kohen al-Attár's prescriptions about the exact composition of the mixture that Nubian women wanted to use to find an effective charm ${ }^{3}$.

In Cairo, Meyerhof was in daily contact with the centuries-old tradition, of an era largely forgotten by the West and yet still alive.

By the time World War I started, Meyerhof's cultural interests had expanded. Not only was he interested in the branches of Arab medicine and its related sciences, but he was also aware of the basic relationship of Islam to the Greco-Roman and Byzantine cultures.

He returned from Germany again in 1923, with a new ambition: to write a history of Arabic medicine based on all available original sources.

Several of his articles describe the medical and pharmaceutical knowledge of the Egyptians, their trade, their bazaars, and the use of narcotics.

In his historical and philological studies, pharmacology and botany claimed his interest and he discussed the content of various pharmacology texts of authors such as Idrisi, Ghafiqi, Biruni or Maimonides, and he frequently edited and translated manuscripts found in the library. He analyzed the influence of Dioscorides on medieval Arab pharmacology and the ascendancy of the Arabs in the vocabulary of drugs in Spain and Portugal. Many of his philological writings originate from the desire to correct the available oriental dictionaries, reveal the appropriate etymology of drug names or trace the exact meaning of some medical or ocular term ${ }^{3}$.

Another topic handled by Meyerhof was the Egyptian history of the $18^{\text {th }}$ and $19^{\text {th }}$ centuries, the endemic diseases of that region, especially those reported by travelers and doctors who arrived there and the measures adopted to control those diseases. He described the ophthalmia that weakened Napoleon's army in 1798, the role of British surgeons and French physicians in the development of several institutions for the control of eye diseases, the history of the plague from 1798 to 1802 in Egypt, and the observations made by Dr. Wolmar, a witness and probably the first to describe cutaneous leishmaniasis or "Aleppo fever». In Jabarti's chronicle (1754-1822) he found that dengue fever had been known in Egypt since 1799, while Qalqasandi's encyclopedia, from the $14^{\text {th }}$ century, mentioned sleeping sickness for the first time. Meyerhof also studied the first printed reports of travelers from the East Indies, in the $17^{\text {th }}$ century, on tropical diseases ${ }^{3}$.
The main activity of Meyerhof was the analytical investigation of Arab culture in the Middle Ages, and its restoration from original unpublished documents. Its merits can best be appreciated by a superficial review of the manuscripts and printed publications of medieval Arab authors that served Meyerhof as sources in his historical studies and as references in his commentaries, of the material he translated, or of the texts taken to press. His manuscript sources were obtained mainly from the libraries of Cairo, but many others were sent to other collections in Islamic countries or to Europe and America.

One of his most interesting articles, in our opinion, is A short history of ophthalmia during the Egyptian Campaigns of 1798-18074.

In this work he concludes, after making a detailed description of foreign incursions into Egypt, that the descriptions of "Egyptian" ophthalmia by military doctors were vague, except in the case of an acute purulent form identified as gonorrheal conjunctivitis. The description of the chronic sequelae of the disease was insufficient and without John Vetch's images of the granulations, it would not have been possible to decide whether or not they were trachoma elements. He adds that it was only after 1820 that more detailed descriptions of ophthalmia militaris seu Aegyptiaca could be found in the literature, and that it could then be established that genuine trachoma was a frequent sequel to this form of conjunctivitis and that the forms of the "Egyptian ophthalmia" described by their predecessors corresponded to an acute catarrhal conjunctivitis, an acute purulent conjunctivitis, post-gonorrhea conjunctivitis, or to genuine trachoma.

Max Meyerhof is, without a doubt, one of the great ophthalmologists, both in the clinical-surgical and historical fields, that should not be forgotten and that, as indicated by Dr. Manuel Márquez, a teacher at the Complutense University and at the Instituto Politécnico Nacional in Mexico: "The ophthalmologist must be, and almost always is, a perpetual student, and must keep his ophthalmological culture - in addition to his general medical culture and his general non-medical culture - at the level of the progress of the time in which he lives"5.

\section{References}

1. Mayer CF. Arabism, Egypt, and Max Meyerhof. Bull Hist Med. 1946;XIX(4):377-400.

2. MacCallan AF. The history of ophthalmology in Egypt. Br J Ophthalmol. 1927;11(12):602-9.

3. Gorin G. History of ophthalmology. Wilmington, Delawere: Publish or Perish, Inc.; 1982. p. 273.

4. Meyerhof M. A short history of ophthalmia during the Egyptian campaigns of 1798-1807. Br J Ophthalmol. 1932;16(3):129-52.

5. Márquez M. Oftalmología especial teórica y práctica. México: La Prensa Médica Mexicana; 1952. 